\title{
PREVENTION OF PRESSURE INJURIES IN THE PRONATION OF COVID-19 PATIENTS: CONSTRUCTION OF A GRAPHIC NARRATIVE
}

\author{
Daniela Soldera ${ }^{1, *} \mathbb{D}$, Cilene Fernandes Soares ${ }^{2}$ (D) Juliana Balbinot Reis Girondi ${ }^{3}$ (D),

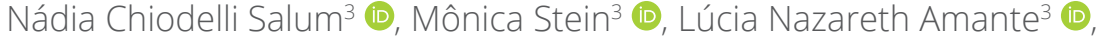 \\ Luciara Fabiane Sebold ${ }^{3}$ (D), Gisele Martins Miranda ${ }^{4}$ (1)
}

\begin{abstract}
Objective: build and validate the content of a graphic narrative on the prevention of Pressure Injury in the prone position in patients affected by the Coronavirus. Method: descriptive methodological study. For the construction of the graphic narrative, a scope review was carried out. Narrative content validation was performed by nurses working in stomatherapists in respiratory intensive care units in Santa Catarina, who responded to a form on Googleforms ${ }^{\circledR}$ with response options from disagree to agree. Data analysis was performed using the Content Validity Index, considering appropriate $>0.80 \%$. Results: the care listed to compose the narrative were: skin assessment; keeping the skin clean and hydrated; use of pressure redistribution devices; use of silicone foams, transparent films, barrier-forming spray and silicone on bony prominences, under medical devices and on the face. The recommended position is that of the swimmer, repositioning the patient every two hours. Conclusion: the graphic narrative was valid for expert nurses whose emphasis is on preventive care in order to promote the engagement of the Nursing team in the face of the importance of Pressure Injury prevention in the care of patients with Coronavirus and prone.
\end{abstract}

DESCRIPTORS: Pressure injury. COVID-19. Prone. Nursing care. Advanced nursing practice. Stomatherapy.

\section{PREVENÇÃO DE LESÕES POR PRESSÃO NA PRONAÇÃO DE PACIENTES COVID-19: CONSTRUÇÃO DE UMA NARRATIVA GRÁFICA}

\section{RESUMO}

Objetivo: construir e validar o conteúdo de uma narrativa gráfica sobre a prevenção de Lesão por Pressão na posição prona em pacientes acometidos pelo Coronavírus. Método: estudo metodológico descritivo. Para a construção da narrativa gráfica, foi realizada a revisão de escopo. A validação de conteúdo da narrativa foi realizada por enfermeiros atuantes em unidades de terapia intensiva respiratória estomaterapeutas de Santa Catarina, os quais responderam a um formulário no Googleforms ${ }^{\circledR}$ com opções de resposta de discordo a concordo. A análise de dados foi realizada por meio do Índice de Validade de Conteúdo, considerando adequado > 0,80\%. Resultados: os cuidados elencados para compor a narrativa foram: avaliação da pele; manutenção da pele limpa e hidratada; utilização de dispositivos de redistribuição de pressão; utilização de espumas de silicone, filmes transparentes, spray formador de barreira e silicone sobre as proeminências ósseas,

1. Universidade Federal de Santa Catarina - Gestão do Cuidado em Enfermagem - Florianópolis (SC), Brazil.

2. Universidade Federal de Santa Catarina - Hospital Universitário - Secretaria Municipal de Saúde - Florianópolis (SC), Brazil.

3. Universidade Federal de Santa Catarina - Centro de Ciências da Saúde - Departamento de Enfermagem - Florianópolis (SC), Brazil.

4. Universidade Federal de Santa Catarina - Gestão do Cuidado em Enfermagem - Florianópolis (SC), Brazil.

*Correspondence author: danielasoldera@hotmail.com

Section Editor: Manuela de Mendonça F Coelho

Received: Out. 04, 2021 | Accepted: Dez. 21, 2021

How to cite: Soldera D; Soares CF; Girondi JBR; Salum NC; Stein M; Amante LN; Sebold LF; Miranda GM. Prevention of pressure injuries in the pronation of Covid-19 patients: construction of a graphic narrative. ESTIMA, Braz. J. Enterostomal Ther., 2021, 19: e2921. https://doi.org/10.30886/estima.v19.1136_IN 
sob dispositivos médicos e em face. A posição recomendada é a do nadador, reposicionando o paciente a cada duas horas. Conclusão: a narrativa gráfica foi validada para enfermeiros experts cujo destaque está para os cuidados preventivos no sentido de promover o engajamento da equipe de Enfermagem frente à importância da prevenção da Lesão por Pressão no cuidado ao paciente com Coronavírus e pronado.

DESCRIPTORS: Lesão por pressão. COVID-19. Decúbito ventral. Cuidados de enfermagem. Prática avançada de enfermagem. Estomaterapia.

\title{
PREVENCIÓN DE LESIONES POR PRESIÓN EN LA PRONACIÓN DE PACIENTES COVID-19: CONSTRUCCIÓN DE UNA NARRATIVA GRÁFICA
}

\begin{abstract}
RESUMEN
Objetivo: construir y validar el contenido de una narrativa gráfica sobre la prevención de Lesión por Presión en la posición prona en pacientes afectados por el Coronavirus. Método: estudio metodológico descriptivo. Para la construcción de la narrativa gráfica, se realizó la revisión del alcance. La validación de contenido de la narrativa fue realizada por enfermeros que trabajan en unidades de terapia intensiva respiratoria estomaterapeutas de Santa Catarina, quienes respondieron a un formulario en Googleforms ${ }^{\circledR}$ con opciones de respuesta de desacuerdo a acuerdo. El análisis de los datos se realizó por medio del Índice de Validez de Contenido, considerando adecuado > 0,80 \%. Resultados: las precauciones enumeradas para componer esta narrativa fueron: evaluación de la piel; mantenimiento de la piel limpia e hidratada; utilización de dispositivos de redistribución de presión; utilización de espumas de silicona, películas transparentes, espray formador de barrera y silicona sobre las prominencias óseas, bajo dispositivos médicos y en la cara. La posición recomendada es la del nadador, reposicionando al paciente cada dos horas. Conclusión: la narrativa gráfica fue válida para enfermeros expertos cuyo énfasis está para los cuidados preventivos en el sentido de promover el compromiso del equipe de Enfermería frente a la importancia de la prevención de la Lesión por Presión en el cuidado al paciente con Coronavirus y propensos.
\end{abstract}

DESCRIPTORES: Lesión por presión. COVID-19. Decúbito ventral. Cuidados de enfermería. Práctica avanzada de enfermería. Estomaterapia.

\section{INTRODUCTION}

In mid-March 2020, the World Health Organization defined a pandemic situation due to the significant increase in cases of COVID-19, an infectious disease caused by the new Coronavirus (SARS-CoV-2)1.

Patients affected by COVID-19 may be asymptomatic, present mild clinical symptoms, or develop a severe or fatal condition characterized by pneumonia with severe respiratory compromise, requiring hospitalization in the Intensive Care Unit (ICU), evolving with endotracheal intubation, hemodynamic instability and septic shock ${ }^{2}$.

Among the procedures adopted for the treatment of Acute Respiratory Distress Syndrome (ARDS), the maintenance of the patient in the prone position applied in the first 48 hours, keeping the patient at least 16 hours prone, is considered. Such a condition significantly increases the risk of developing Pressure Injuries (PI) and Medical Device Related Pressure Injuries (MDRPI) $)^{3,4}$.

The National Pressure Injury Advisory Panel (NPIAP) warns that patients with COVID-19 present, due to the pathophysiology of the disease, conditions such as systemic coagulopathy, hypercatabolism and nutritional deficit, which make them more susceptible to the appearance of skin lesions, namely, PI. ${ }^{5}$.

The motivation for the construction of a graphic narrative based on scientific evidence about preventive care of PI during the prone position of the patient with COVID-19 was given by the experience in clinical practice and the daily challenge of providing the best assistance for this care. It is observed that the Nursing teams, at this moment, are exhausted and, 
often, skin care and PI prevention may not be being fully developed, either due to lack of time to update this knowledge. or by the work overload, even affecting the emotional lability of these professionals.

The worsening of the scenario of difficulties in the Nursing work process in the pandemic raises the potential for impact on the mental health of workers due to suffering, the scarcity of Personal Protective Equipment (PPE), the fragility in the description of protocols and flows for control infections, lengthening working hours, inadequate professional training for the crisis scenario and uncertainties regarding therapeutic measures ${ }^{6}$.

In this context, it was identified, through the use of educational technologies, the opportunity to contribute to the learning of nurses on the front line. The use of technological resources for pedagogical purposes is an innovative practice that facilitates and enhances the teaching and learning process ${ }^{7}$.

Among the existing technologies, graphic narratives are content presented using a combination of words and sequential art. The carefully constructed text and image illustrations act as facilitators in the learning process ${ }^{8}$.

In recent years, the effectiveness of arts-based education, particularly in comics and graphic novels, has been increasingly studied and identified, where the fusion of text and image proves useful in a media-oriented world 9

It is worth mentioning the importance of developing educational technologies based on scientific evidence focused on Nursing, especially validated by judges. In this sense, the validation of educational technologies fosters the potential for articulating health education with the various technologies developed, since the validation process ascertains the ability of a given technology to achieve its proposed objective ${ }^{10}$.

In view of these findings, the research question emerged: "Which care related to the prevention of PI during pronation of patients with COVID-19 should compose a graphic narrative?". The need to have, accessible and in a simplified way, the best evidences for care impelled the authors to develop this educational technology so that this knowledge is widely disseminated, enabling safe and effective practices to be implemented.

This study aimed to build and validate a graphic narrative about preventive care of PI during prone in patients affected by COVID-19.

\section{METHOD}

This is a methodological study. This was aimed at the construction and validation of an educational technology, of the comic book type, in order to contribute to the improvement of the Nursing team's knowledge about PI preventive care during the prone position in patients with COVID-19.

The product was developed from March to July 2021. The steps for construction were: scope review, content validation to compose the graphic narrative and validation of the graphic narrative by intensive care nurses and/or experts in Stomatherapy.

In the first step, a scope review was carried out to investigate the preventive care of PI in patients with COVID-19 during the prone position. To construct the research question, the Population, Concept, Context (PCC) strategy was used, as recommended by the Joanna Briggs Institute (JBI)11, defining: P - patient with COVID-19; $\mathrm{C}$ - prevention; $\mathrm{C}$ - hospital care. From now on, the research question was: "What scientific evidence on the prevention of PI in patients with prone COVID-19 is there in the national and international literature?".

The search was carried out in the National Library of Medicine (PubMed), Scopus Review (Elsevier) and Scientific Electronic Library Online (SciELO) databases, with a time frame from 2020 to March 2021, in English, Portuguese and Spanish. The following descriptors were used: "prone position"; "prone"; "proning”;"Hospital Care”; “Coronavirus Infection”; “Coronavirus Infections”; "pressure ulcer”; “Decubitus ulcer”. The review guided the construction of content to compose the graphic narrative. As inclusion criteria, the following were defined: qualitative and/or quantitative research studies on the topic; essay; consensus published in journals from the databases selected for the study; and studies that contained the descriptors and keywords provided for in the search protocol. Duplicate studies, letters, editorials, abstracts published in annals of events and/or journals, books, dissertations, 
theses, programs, health policies, literature review, experience reports, theoretical reflection or that do not meet the defined languages were excluded.

The second stage comprised the validation of the content to compose the graphic narrative. A Google forms ${ }^{\circledR}$ form was structured with LP preventive care for patients in prone position diagnosed with COVID-19 and validation was required regarding the agreement of care. The data obtained in the validation of the judges were grouped and analyzed using the Content Validity Index (CVI).

The CVI measures the proportion or percentage of judges in agreement on certain aspects of an instrument and its items ${ }^{11}$. This method consists of a Likert scale with a score of 1 to 4 , where: 1 = disagree; 2 = partially disagree; 3 = partially agree; and $4=$ agree. To calculate the CVI of each item in the instrument, just add the answers 3 and 4 of the experts committee participants and divide the result of this sum by the total number of answers ${ }^{12}$.

The statistical treatment considered the following categories: completely adequate and adequate for those who obtained a consensus $\geq 80 \%(0.8)$, and this agreement index was based on validation studies, since, in order to verify the validity of the content in its completeness, the minimum agreement between the judges must be 0.80 and, preferably, greater than $0.90^{12}$.

At this stage, 26 nurses working in hospitals in Greater Florianópolis were intentionally invited to participate, identified through the Snowball technique, in which a professional with expertise in a certain topic indicates another, and so on. However, 14 nurses participated in this stage. The criterion used for the classification of experts was the degree in Intensive Care and/or Stomatherapy. The following exclusion criteria were listed: nurses on leave during the data collection period or non-return in eight days.

After content validation, the construction of the comic book began through the Pixton ${ }^{\circledR}$ online tool, which allows the creation of this type of educational technology.

The third step consisted of validating the content of the educational technology through the prior presentation of the graphic narrative. This took place through the structuring of a new form in Google forms ${ }^{\circledR}$, forwarded to the examiners who composed the previous content validation stage, following the same inclusion and exclusion criteria. Validation was proposed regarding agreement, clarity, coherence, relevance, objectivity ${ }^{13}$, as well as the evaluation of the layout presentation, the contribution of educational technology to the nursing care practice in the face of the prevention of PI in patients with COVID-19 during the prone position and, finally, opinions and suggestions to improve the graphic narrative.

The study was approved by the Ethics Committee in Research with Human Beings (Comitê de Ética em Pesquisa com Seres Humanos -CEPSH) through the opinion embodied in CAAE $\mathrm{n}^{\circ}$ 12212519.2.0000.0121.

\section{RESULTS}

In the first stage, a scope review was carried out, which totaled 107 articles found. After reading the titles and abstracts, 43 articles were selected to compose the construction of the graphic narrative. Among the studies listed, 12 were excluded due to duplicity and 26 because they did not fully cover the topic, were incomplete or unavailable for free access. Thus, the final sample consisted of five eligible studies. Of these, three studies had a qualitative or quantitative approach, one study was a prospective cohort and there was a scoping review. Three studies were published in 2020 and two in 2021. As for the language, all were in English.

The care listed in the scope review comprised: skin assessment; use of pressure redistribution devices under bony prominences; application of barrier-forming spray and eye cream for eye protection; maintain the swimmer's position; reposition the patient every two hours; keep the skin clean and hydrated; use redistribution supports to relieve pressure points on the face and body; verify the pressure redistribution in exclusive points of the prone position and positioning of medical devices; apply prophylactic silicone dressings over bony prominences and under medical devices; assess the skin before pronation and after repositioning to the supine position; and apply hydrocolloid dressings, five-layer

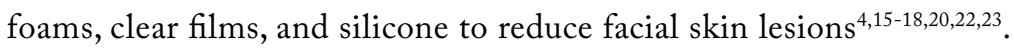


In the second stage, the content of the graphic narrative was validated. The sample was by intentionality, composed of 14 evaluator nurses, predominantly female ( $n=13$ ), all of whom were titled, mostly, as masters ( $n=8)$, followed by specialists $(\mathrm{n}=5)$ and a doctor. Regarding the time working in the profession, most worked between 11 and 15 years $(n=4)$. As for the area of activity, the highest concentration was in the hospital environment $(n=11)$ and in activities specifically related to Stomatherapy $(n=3)$.

Table 1 presents the main recommendations found in the articles and validated by experts on the necessary care before positioning the patient with COVID-19 in prone.

Table 1. Main recommendations before positioning the patient in prone. Florianópolis (SC), Brasil - 2021.

\begin{tabular}{lc}
\hline CARE & CVI \\
\hline Evaluate the skin & 92.9 \\
\hline Use pressure redistribution devices on bony prominences & 92.9 \\
\hline Use appropriate mattresses & 100 \\
\hline Apply barrier-forming spray & 92.9 \\
\hline Apply eye cream for eye protection and keep eyelids closed & 92.9 \\
\hline CVI = Content Validity Index.
\end{tabular}

$\mathrm{CVI}=$ Content Validity Index

Table 2 presents the main recommendations found in the articles and validated by experts on the necessary care to be performed when the patient with COVID-19 is in prone.

Table 2. Implementation strategies for the prevention of Pressure Injury during prone. Florianópolis (SC), Brasil - 2021.

\begin{tabular}{ll}
\hline CARE & CVI \\
\hline Maintain swimmer's position & 85.7 \\
\hline Reposition the patient every two hours & 92.9 \\
\hline Keep the skin clean and hydrated & 100 \\
\hline Use redistribution supports to relieve pressure points on the face and body & 100 \\
\hline Check pressure redistribution at points exclusive to the prone position and positioning of medical devices & 92.9 \\
\hline Ese prophylactic silicone dressings over bony prominences and under medical devices & 92.9 \\
\hline Apply hydrocolloid dressings, five-layer foams, clear films, and silicone to reduce facial skin lesions.
\end{tabular}

$\mathrm{CVI}=$ Content Validity Index.

After the validation of care related to the prevention of PI during the prone position of the patient with COVID-19, the graphic narrative was constructed (Figs. 1, 2 and 3) using the Pixton ${ }^{\circledR}$ tool. The narrative is available in full through the link: https://share.pixton.com/qr48ahb. 


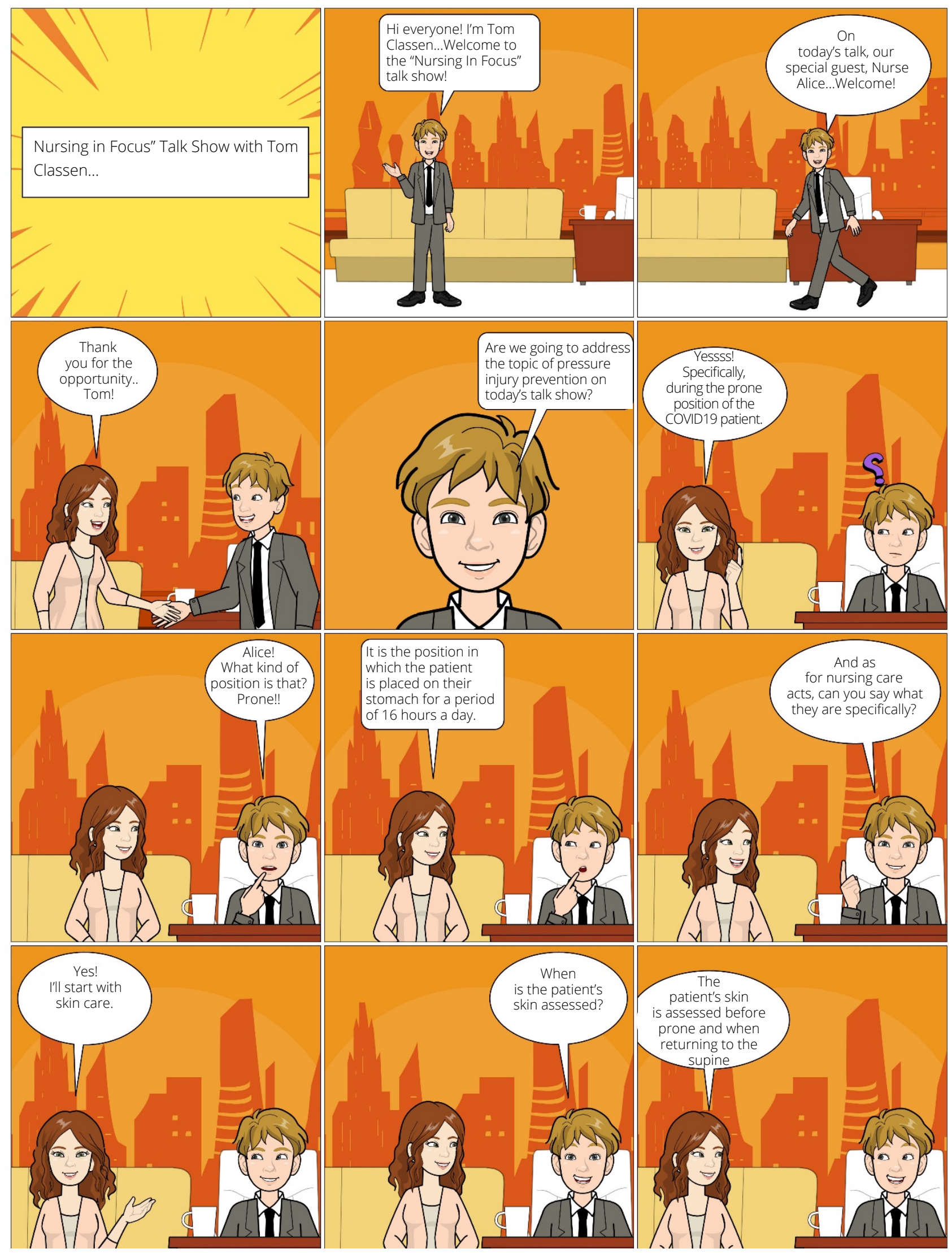

Figure 1. Graphic narrative screens. Florianópolis (SC), Brasil - 2021. 


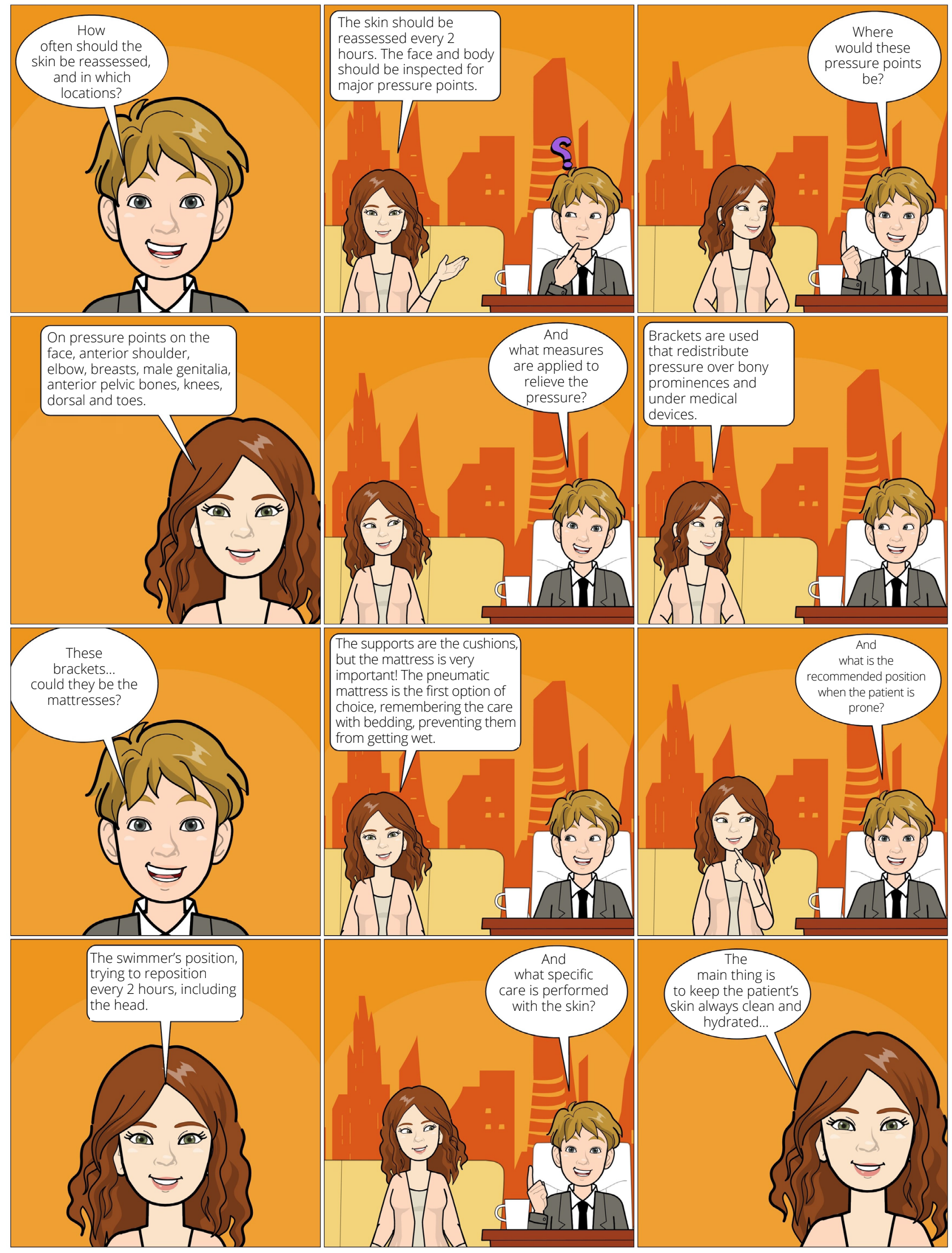

Figure 2. Graphic narrative screens. Florianópolis (SC), Brasil - 2021. 

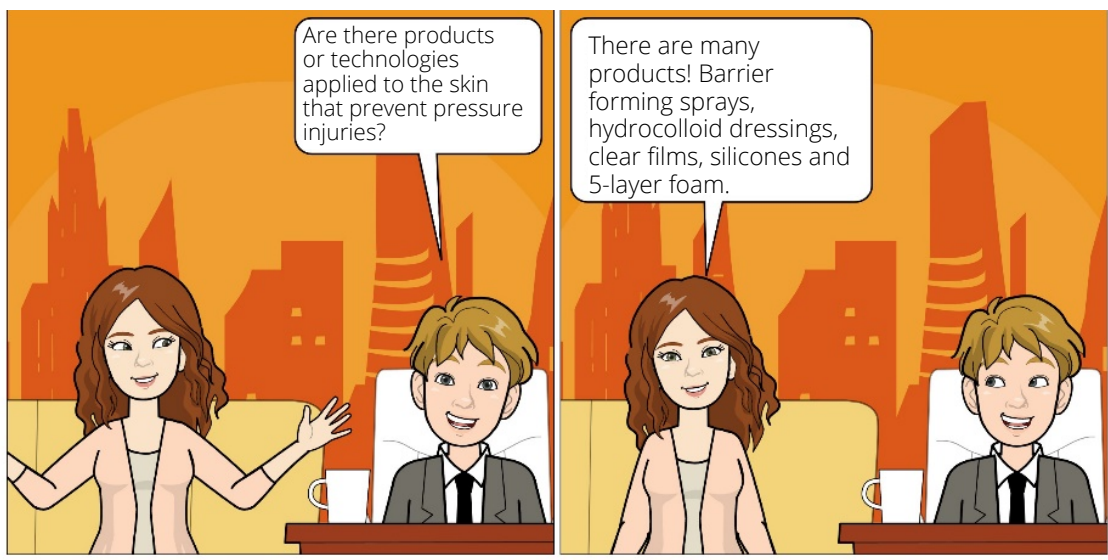

Aaaaah ... remembered a very

important thing to do to avoid corneal

injury. For eye protection, an eye

cream prescribed by the doctor is

applied 2 to 3 times a day, keeping the patient's eyes closed. A tape can be used for fixation.
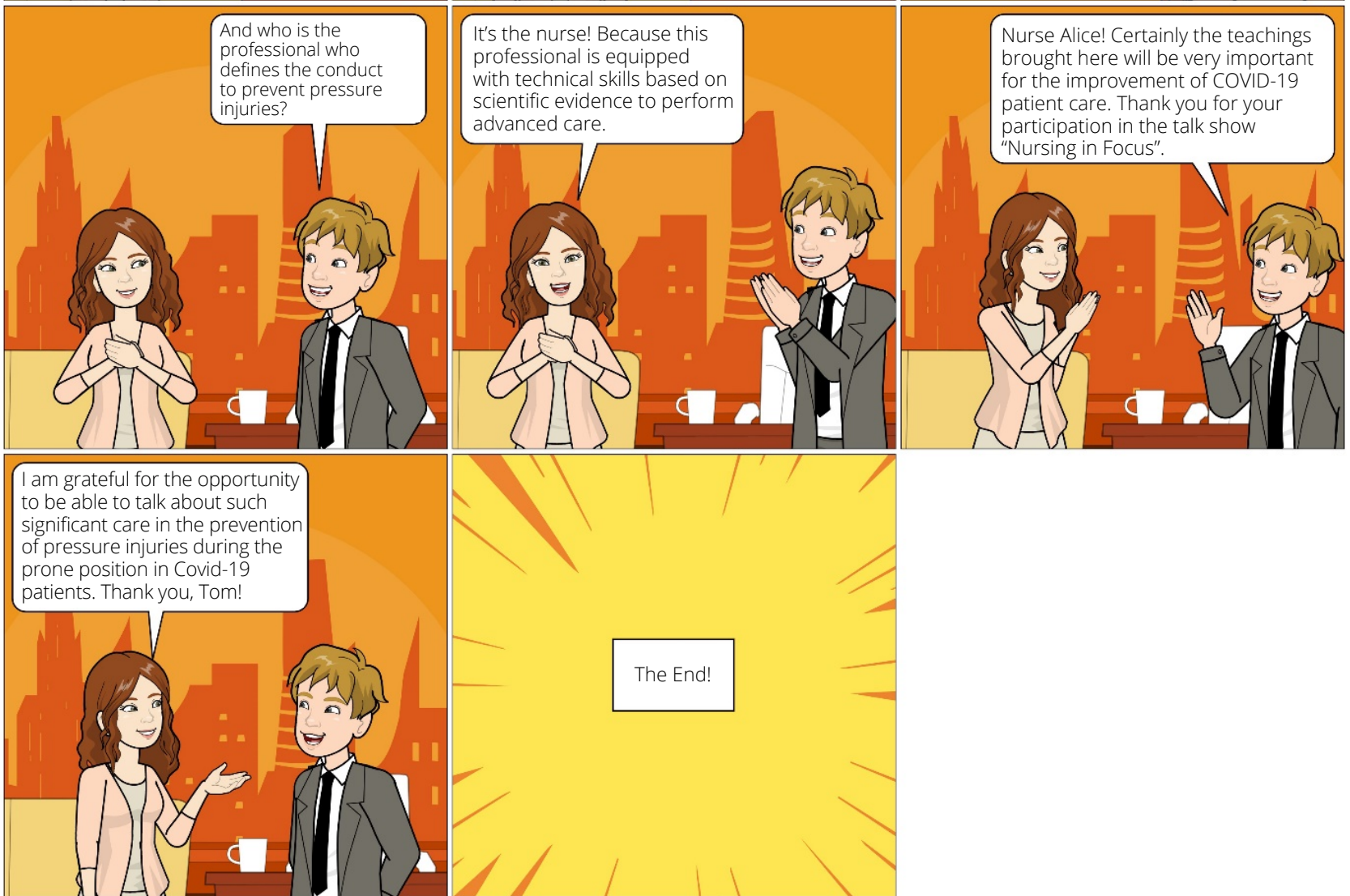

Figure 3. Graphic narrative screens. Florianópolis (SC), Brasil - 2021.

In the third and final stage, the validation of the graphic narrative regarding appearance and content was carried out by the 14 evaluator nurses who participated in the second stage, according to the inclusion criteria. The content was presented to the experts through a file in which they could individually evaluate each of the screens of the graphic narrative regarding the content of the dialogues, the images and characteristics of the characters and the layout presented. At this stage, $100 \%$ of the experts agreed, given that they had validated the care addressed in the narrative.

When asked whether the graphic narrative is considered a form of wide-ranging knowledge dissemination, 12 consider it to be yes and 14 consider that educational technology contributes to nurses' care practice in the face of PI prevention during the prone position.

Finally, the examiners were asked to evaluate the educational technology developed, making suggestions or opinions that could contribute to the improvement of the material. The findings are described below. 
It was very enlightening and detailed [...] it was a rich experience that managed to clarify some doubts that I still had, such as time to evaluate the injuries. I had no doubts. Great. (E1)

Very didactic!!! Used technologies to teach in a fun way. (E3)

Currently, a large percentage of the population has access to the internet through a mobile device. For example, cell phones promote agility and ease of communication and, for those who want to make good use of this technology, acquiring knowledge through a graphic narrative is innovative. The transposition of verbal text into visual text is an efficient method of communication and learning. (E4)

Very educational content. It would be interesting to point out that, in obese and edematous patients, care should be more intensive, because, in these conditions, the appearance of PI is greater, mainly due to medical devices. (E5)

It could be a more colloquial language to really spread knowledge. (E7)

Excellent product. Attractive and objective form of training. (E8)

At the end of the validation of the graphic narrative by the experts, the copyright registration was requested at the Câmara Brasileira do Livro (Brazilian Book Chamber)

\section{DISCUSSION}

This study was structured from the scope review of Nursing care for the prevention of PI during the prone position in patients affected by COVID-19 and validated by nurses working in the COVID ICU and/or stomatherapists who are experts in skin care, and then proceed with the construction of the graphic narrative.

Pronation of the patient with COVID-19 helps the treatment of ARDS, therefore, it is necessary to remain in this position for up to 16 hours a day, alternating it every 8 hours for the supine position, although this position increases the risk of $\mathrm{PI}^{14}$.

Patients with hemodynamic and/or respiratory instability treated in ICUs present a clinical picture of risk for the development of PI resulting from the use of vasoactive drugs, sedation, invasive mechanical ventilation, among others ${ }^{15}$. Thus, they may show deterioration of skin integrity in a matter of hours. In addition to the natural pressure points on the body resulting from the proposed position, another aggravating factor is the multiple medical devices used ${ }^{16}$.

In this context, the prevention of PI is a challenge for Nursing, as the changes resulting from the infection expose the patient to greater instability, less tissue oxygenation, prolonged hospital stay in a critical unit and difficulty in repositioning ${ }^{16}$.

The nurse, with the autonomy and decision-making capacity for advanced care aimed at preventing this condition, must first perform the assessment of the patient's skin before the prone position, so that he can apply the necessary conducts such as the use of devices or supports that redistribute and relieve pressure on bony prominences, as well as the choice of appropriate mattresses to reduce the incidence of this condition ${ }^{4}$.

By emphasizing eye care, direct pressure on the orbits, together with vascular changes, causes extraocular muscle impact, triggering conjunctival edema, hemorrhage and corneal injury, which can already be observed approximately ten minutes after this positioning ${ }^{17}$.

The position of choice during the prone position is that of a swimmer so that the face is facing towards the bent arm and the other arm remains facing backwards. This position allows movement of the head, endotracheal tube, and nasoenteral tube at the same time and should be performed every two hours., ${ }^{418}$. Also, it is recommended to carry out small repositioning every two or four hours, using the swimmer repositioning technique, in which the position of the arms and head is alternated ${ }^{16}$. 
With regard to repositioning, early mobilization becomes a priority, as the pathophysiology of SARS-CoV-2 must be considered in relation to the risk of severe thrombosis. The position and duration of this placement therefore need to be documented ${ }^{19}$. In addition to reducing vascular complications, repositioning and pressure relief are Nursing interventions that reduce the risk of PI.Therefore, it is up to the nurse with their expertise to coordinate the team during the repositioning, since, on average, six to seven professionals are involved in providing this care ${ }^{20,21}$.

In this sense, the first concern is with the skin, which must be kept clean and hydrated, as moisture causes tissue maceration, increasing the risk of PI. Regarding cleaning, it is recommended to use soaps for the bath with a slightly acidified $\mathrm{pH}$, which approximates the physiological $\mathrm{pH}$ of the skin. Other types of soap and antiseptics are not recommended due to the risk of causing irritation and drying of the skin..$^{4,16,22}$.

In relation to humidity, attention should be redoubled with patients with incontinence (urine and/or feces), exuding lesions, leaking stomas, among other situations. In these cases, in addition to constant inspection, it is recommended to use barrier protection products, associated with ready-to-rinse products for cleaning the skin of the perigenital area and surroundings, with surfactants and acidic $\mathrm{pH}^{23}$.

The importance of evaluating and adequate adaptation of the support surface, as well as cushions and pillows, is highlighted ${ }^{24}$. The main pressure points in this placement are: forehead, cheek, chin, collarbone, elbow, inframammary region, genitals, pelvis, knees, back and toes and regions adjacent to medical devices ${ }^{16}$.

Other essential measures must be adopted, including the global clinical assessment of the patient and appropriate interventions for the management of intercurrences. It is still important to be careful about rotating the oximeter site and other devices whenever possible ${ }^{16}$.

The assessment of the skin before and after the prone position should be a thorough care performed by the nurse to assess the quality of care provided and the preventive measures, whether they were effective or not. Daily skin inspection is necessary in view of the rapidly changing risk factors in these acute patients, such as those infected with COVID-19. For pressure redistribution, in addition to those mentioned above, silicone foam can be used at points where there is pressure on bony prominences ${ }^{22}$. Also, to help relieve pressure and reduce skin friction at the interface of medical devices, silicone foam can be used to reduce the risk of $\mathrm{PI}^{16,25}$.

In this process, it is up to nurses to perform advanced nursing care, in order to prevent the development of PI during the prone position in patients with COVID-19, especially in obese and edematous patients, because after the development of PI, it becomes costly for health systems, which may interfere with patient recovery, increasing hospital stay and with potential risk of fatal complications from sepsis².

The NPIAP4 reinforces the importance not only of ensuring the implementation of the practices reported here, but also that all Nursing interventions are properly performed and recorded in the patients' charts, warning that, in this way, it can be concluded that, if the patient develops PI, this could be considered inevitable ${ }^{16}$.

Finally, it is highlighted that graphic narratives are still little explored as an academic resource, especially in Nursing. For this reason, the article aimed to present this tool as a possibility to generate rapid, practical and objective learning, bringing greater reader involvement with the instrument and, above all, the ease of dissemination through digital media.

\section{Study limitations}

As a limitation, validation with experts from a certain geographic region is considered, which can portray part of the problem studied.

\section{Contributions to practice}

As contributions to practice, the way in which the scientific content was structured through a graphic narrative is a technological innovation for the area of Nursing, given the possibility of large-scale dissemination through social media. 


\section{CONCLUSION}

When considering the context of Advanced Practice in Nursing, in which the integration between the pillars of education, research, care practice and management for professional development occurs, the elucidated theme contemplates advanced Nursing care, as nurses develop skills and have autonomy and decision-making to perform LP preventive care during patients' pronation, especially in an intensive care setting.

The proposed objective of validating preventive care with intensive care nurses and/or stomatherapists was achieved, with a consensus on the conduct developed by both specialties. The development of the graphic narrative on preventive care seeks to promote and engage the Nursing team in the face of the importance of preventing PI while the patient remains in a prone position.

The graphic narrative is considered an innovative technology among the products developed in the area of Nursing, which aims to demonstrate, to the academic and care community, that it is possible to use playfulness to learn and teach.

\section{AUTHORS' CONTRIBUTION}

Conceptualization: Soldera D and Girondi JBR; Methodology: Soldera D and Girondi JBR; Investigation: Soldera D and Girondi JBR; Writing - First version: Soldera D, Girondi JBR, Soares CF, Amante LN, Sebold LF, Salum NC, Stein M and Miranda GM; Writing - Reviewing \& Editing: Soldera D, Girondi JBR, Soares CF, Amante LN, Sebold LF, Salum NC, Stein M and Miranda GM.

\section{DISPONIBILIDADE DE DADOS DE PESQUISA}

All the date is on the current manuscript.

\section{FUNDING}

Not applicable.

\section{ACKNOWLEDGMENTS}

Not applicable.

\section{REFERENCES}

1. World Health Organization. Rational use of personal protective equipment for coronavirus disease (COVID-19): Interim guidance. World Health Organization. 2020. [Cited 2021 Mar 21]. Disponível em: https://apps.who.int/iris/bitstream/ handle/10665/331215/WHO-2019-nCov-IPCPPE_use-2020.1-eng.pdf

2. Associação de Medicina Intensiva Brasileira. Coronavírus: esclarecimentos da AMIB pelo Comitê de Sepse e Infecção. 2020. São Paulo: AMB (SP); 2020. Disponível em: https://www.amib.org.br/fileadmin/user_upload/amib/2020/marco/21/11_ CORONAVIRUS_Esclarecimentos_da_AMIB_pelo_Comite_de_Sepse_e_Infeccao.pdf

3. Véras JB, Martinez BP, Neto MG, Saquetto MB, Conceição CS, Silva CM. Efeitos da posição prona em pacientes com síndrome do desconforto respiratório agudo: uma revisão sistemática. Rev Pesqui Fisioter 2019;9(1):129-138. https://doi.org/10.17267/22382704rpf.v9i1.2175

4. European Pressure Ulcer Advisory Panel, National Pressure Injury Advisory Panel and Pan Pacific Pressure Injury Alliance. Prevention and Treatment of Pressure Ulcers/Injuries: Quick Reference Guide. Emily Haesler (Ed.). EPUAP/NPIAP/PPPIA. 2019. [Cited 2021 Mar 20]. Disponível em: http://www.internationalguideline.com/static/pdfs/Quick_Reference_Guide-10Mar2019. pdf 
5. Black J, Cuddigan J, Capasso V, Cox J, Delmore B, Munoz N et al. On behalf of the National Pressure Injury Advisory Panel. Unavoidable Pressure Injury during COVID-19 Crisis: A Position Paper from the National Pressure Injury Advisory Panel. 2020. [Cited 2021 Mar 20]. Disponível em: https://cdn.ymaws.com/npiap.com/resource/resmgr/white_papers/Unavoidable_in_ COVID_Pandemi.pdf

6. Souza NVDO, Carvalho EC, Soares SSS, Varella TCMML, Pereira SRM, Andrade KBS. Nursing work in the COVID-19 pandemic and repercussions for workers' mental health. Rev Gaúcha Enferm. 2021;42(spe):e20200225. https://doi.org/10.1590/19831447.2021.20200225

7. Machado GB, Wives LK, Grandi R. As comunidades de prática como ferramenta para formação continuada de professores: percepções docentes sobre o uso da tecnologia para compartilhamento e aprimoramento das práticas pedagógicas. Anais do XXX SBIE. 2019; 1991-2004. https://doi.org/10.5753/cbie.sbie.2019.1995

8. Green MJ, Myers KR. Medicina gráfica: uso de quadrinhos na educação médica e no atendimento ao paciente. BMJ. 2010; 340:c863. https://doi.org/10.1136/bmj.c863

9. Albright KS, Gavigan, K. Information Vaccine: Using Graphic Novels as an HIV/AIDS Prevention Resource for Young Adults. J Educ Libr Inf Sci. 2014;55(2) [Cited 2021 Nov 15]: 178-85. Disponível em: https://files.eric.ed.gov/fulltext/EJ1074316.pdf

10. Cassiano AN, Silva CJA, Nogueira ILA, Elias TMN, Teixeira E, Menezes RMP. Validação de tecnologias educacionais: estudo bibliométrico em teses e dissertações de enfermagem. Revista de Enfermagem do Centro-Oeste Mineiro. 2020;10:e3900. http://doi.org/10.19175/recom.v10i0.3900

11. The Joanna Briggs Institute. Joanna Briggs Institute Reviewers manual: 2014 edition: methodology for jbi mixed methods systematic reviews. 2014 [Cited 2021 Mar 20]. Disponível em: https://nursing.Isuhsc.edu/JBI/docs/ReviewersManuals/MixedMethods.pdf

12. Alexandre NMC, Coluci MZO. Validade de conteúdo nos processos de construção e adaptação de instrumentos de medidas. Ciênc Saúde Coletiva. 2011;16(7):3061-68. https://doi.org/10.1590/S1413-81232011000800006

13. Pasquali, L. Psicometria. Revi Esc Enferm. 2009; 43(Esp.):992-9. https://doi.org/10.1590/S0080-62342009000500002

14. Dondorp AM, Hayat M, Aryal D, Beane A, Schultz MJ. Respiratory Support in COVID-19 Patients, with a Focus on ResourceLimited Settings. Am J Trop Med Hyg. 2020;102(6):1191-7. https://doi.org/10.4269/ajtmh.20-0283

15. Souza MFC, Zanei SSV, Whitaker IY. Risco de lesão por pressão em UTI: adaptação transcultural e confiabilidade da EVARUCI. Acta Paul Enferm. 2018;31(2):201-8. https://doi.org/10.1590/1982-0194201800029

16. Ramalho AO, Freitas PSS, Moraes JT, Nogueira PC. Reflexões sobre as recomendações para prevenção de lesões por pressão durante a pandemia de COVID-19. ESTIMA, BrazJ Enterostomal Ther. 2020;18:e2520. https://doi.org/10.30886/estima.v18.940_ PT

17. Saran S, Gurjar M, Kanaujia V, Ghosh PS, Gupta A, Mishra P et al. Effect of Prone Positioning on Intraocular Pressure in Patients With Acute Respiratory Distress Syndrome. Crit Care Med. 2019;47(9):e761-6. https://doi.org/10.1097/CCM.0000000000003893

18. Wounds International TV. COVID-19 and tips for safe skin and proning: What should skin care involve for patients in the prone position?. 2020. [Cited 2021 Mar 20]. Disponível em: https://woundsinternationaltv.com/editors-chioce/covid-19-and-tips-forsafe-skin-and-proning/

19. Magro C, Mulvey JJ, Berlin D, Nuovo G, Salvatore S, Harp J et al. Complement associated microvascular injury and thrombosis in the pathogenesis of severe COVID-19 infection: A report of five cases. Transl Res. 2020;220:1-13. https://doi.org/10.1016/j. $\operatorname{trs} 1.2020 .04 .007$

20. Odor PM, Neun M, Bampoe S, Clark S, Heaton D, Hoogenboom EM et al. Anaesthesia and COVID-19: infection control. Br J Anaesth. 2020;125(1):16-24. https://doi.org/10.1016/j.bja.2020.03.025

21. Lou B, Li TD, Zheng SF, Su YY, Li ZY, Liu W et al. Serology characteristics of SARS-CoV-2 infection after exposure and postsymptom onset. Eur Respir J. 2020;56(2): 2000763. https://doi.org/10.1183/13993003.00763-202

22. Black, J, Alves P, Brindle CT, Dealey C, Santamaria N, Call E et al. Use of wound dressings to enhance prevention of pressure ulcers caused by medical devices. Int Wound J. 2015;12(3):322-7. https://doi.org/10.1111/iwj.12111

23. Payne D. Skin integrity in older adults: pressure-prone, inaccessible areas of the body. Br J Community Nurs. 2020;25(1):22-6. https://doi.org/10.12968/bjcn.2020.25.1.22

24. Moore Z, Patton D, Avsar P, McEvoy NL, Curley G, Budri A et al. Prevention of pressure ulcers among individuals cared for in the prone position: lessons for the COVID-19 emergency. J Wound Care. 2020;29(6):312-20. https://doi.org/10.12968/ jowc.2020.29.6.312

25. Kim RS, Mullins K. Preventing Facial Pressure Ulcers in Acute Respiratory Distress Syndrome (ARDS). J Wound Ostomy Continence Nurs. 2016;43(4):427-9. https://doi.org/10.1097/WON.0000000000000247 